\title{
RELATIONSHIP LEADERSHIP QUALITY AND CULTURE ORGANIZATION WITH THE PERFORMANCE OF SMAN 28 TANGERANG DISTRICT
}

\author{
Anggih Perian Guswan Putra ${ }^{1}$, Agus Iwan Mulyanto ${ }^{2}$ \\ ${ }^{12}$ Universitas Islam Syekh-Yusuf Tangerang, \\ (anggih.pgp@gmail.com) \\ (ai_mulyanto@unis.ac.id)
}

\begin{abstract}
This research was conducted to determine the relationship between the quality of the Principal's leadership and organizational culture with the performance of SMAN 28 Tangerang District employees. The study uses a quantitative approach with a descriptive correlational survey method, using correlation theory which is about product moment. Research data collection techniques from respondents carried out through questionnaires or questionnaires. The sample population was 103 employees in each section of SMAN 28 Tangerang, with simple random sampling technique. The magnitude of the effect of leadership quality and organizational culture together on employee performance by $87.2 \%$ This shows the higher the quality of leadership and organizational culture, the better the performance of employees, and vice versa the lower the quality of leadership and organizational culture will have an impact for employee performance.
\end{abstract}

Keywords: Leadership Quality, Organizational Culture, Performance

\section{A. Introduction.}

Employee performance is needed in achieving progress in a government system that is characterized by government officials who serve well. Performance for civil servants is something that is important for the creation of good governance and the form of responsibility as a public servant. The community has dared to assess, monitor and evaluate services from government agencies and view employee performance is still low. Low performance will result in poor public services.

One sign of quality employee performance is characterized by discipline in the work unit. Discipline of Civil Servants is regulated in Government Regulation No.53 of 2010 concerning Discipline of Civil Servants, Law No. 20 of 2003, concerning Education, Law No. 14 of 2005 concerning Teachers and Lecturers, and Law No. 5 of 2014 concerning State Civil Apparatus, as regulations and honorary employees both as teaching staff and administrative staff as well as for all apparatuses in carrying out their main duties and functions.

As one of the implementing units of the Ministry of Education and Culture in regulating the discipline of its employees, it must commit to performance promises held in each technical service unit, containing promises to be a role model by providing the 
best performance to the organization, trying to improve competencies and develop their potential according to their needs and demands for the implementation of tasks and functions through e-learning, implementing and developing e-government and orderly offices in the context of realizing good governance, developing and implementing work culture and upholding values and collaboration in order to improve the best service for the community, to improve progress namely realize educators and administrative staff with integrity and high performance.Instructions from the principal as the leader so that each employee improves service by providing information disclosure. This is an expression of the seriousness of the school to always improve itself. Although the reform of educators and administrative staff or other supporting apparatuses is not only through facilities and infrastructure, there is a need for improvements to all employees by making changes to the mind set and culture set. This is not merely done by a few people, but must be done from the top level to the bottom level. The example of the leadership holds the main point in carrying out reforms. Reforms undertaken by the Department of Education include changes in organizational structure in schools, technology, and the application of Human Resources management, such as improving morale, ethics and integrity by implementing fit and proper tests, employee mapping, service policy improvement, school supervision by implementing modern management systems. supported by information technology.

In addition, the system for applying employee discipline needs to be implemented effectively in fostering all staff of educators and administrative who carry out the tasks and have the authority and responsibility of education, containing guidelines, attitudes, behavior, and actions of the educational and administration staff in carrying out their duties and daily life relationships. This code of conduct functions to improve the discipline of educators and administrative staff, ensure the smooth implementation of tasks and a conducive climate, create and maintain working conditions and professional behavior and improve the image and performance of educators and administrative staff. Based on the limitation of the problem, the formulation of the research problem is as follows: 1. There is a positive relationship between the quality of leadership with the performance of educators and administrative staff at SMAN 28 Tangerang; 2. There is a positive relationship between organizational culture and the performance of educators and administrative staff at SMAN 28 Tangerang; 3. There is a positive relationship between the quality of leadership and organizational culture simultaneously with the performance of educators and administrative staff at SMAN 28 Tangerang.

\section{Literature.}

Leadership quality, according to Obiwuru (2011: 101) is "Leadership as the individual behaviour to guide a group to achieve the common target". That is, leadership is the behaviour of an individual who leads to direct the activities of a group to a goal to be achieved together. According to Jyuji Misumi in Kaloh (2009:9), "leadership is an important aspect in management and administration because leadership relates directly to superiors and 
subordinates in an organization". According to Stoner, Freeman and Gilbert (2005), defining leadership "the process of directing and influencing the task-related activities of group members" leadership is the process of directing and influencing members in terms of the various activities that must be carried out.

Furthermore, Griffin (2000), "divides the notion of leadership into two concepts, namely as a process and as an attribute. As a process, leadership is focused on what leaders do, that is, the process by which leaders use their influence to clarify organizational goals for employees, subordinates or those they lead, motivate them to achieve these goals, and help create a productive culture within the organization. As for the attributes, leadership is a collection of characteristics that must be owned by a leader, therefore, the leader can be defined as someone who can influence the behaviour of other people without using force, so that the people they lead accept themselves as someone who deserves to lead them ". Kartini's opinion Kartono (2003: 58) related to leadership is a matter of relations and influence between leaders and those led.From the various definitions above, it can be concluded that the notion of leadership is someone as an example for his subordinates, with his ability to influence and move other people, groups or subordinates, so they are willing to act and behave as expected or directed by those who lead it, to achieve organizational goals.

\section{Organizational culture.}

According to Sutrisno (2011: 2), organizational culture is as follows: "The system of values, beliefs, assumptions, or norms that have long been applied, agreed and followed by members and an organization as a code of conduct and organizational problemsolving."Organizational culture according to Susanto cited by Sudaryono (2014: 36) is: "Values that hold human resources in carrying out their obligations and behaviour within the organization. These values will provide an answer about whether an action is right or wrong and whether a behaviour is recommended or not so that it serves as a foundation for behaviour ".According to Irvan (2009), "organizational culture can be interpreted as a habit that is repeated by employees in an organization. The employee has morally agreed that the habit is a habit that must be obeyed to carry out the work to achieve the goal. In other words, habits that have been firmly rooted in the organization can increase the effectiveness of achieving the vision, mission and goals of the organization can be regarded as organizational culture. This is consistent with the opinion of Munandar(2001: 263) which states that "organizational culture is ways of thinking, feeling, and reacting based on certain patterns that exist within the organization or that exist in parts of the organization".

\section{Teacher and Administrative Staff Performance.}

According to Pabundu (2006) in the book Muhamad Busro (2017: 88), "performance is the result of work produced by an employee interpreted to achieve the expected goals. Performance can also be interpreted as a result of the work function of a person's or group's activities in an organization that is influenced by various factors to achieve organizational goals 
within a certain period ". This opinion is in line with the opinion of Dessler (2011: 41) which states that "performance is work performance, namely the comparison between work results with established standards". Which can be taken from some of the expert opinions above, namely the work achieved by individuals following the duties and responsibilities given within a certain period to achieve organizational goals.

\section{Research methods}

In this study as the population is the teaching staff and administrative staff at SMAN 28 Tangerang District, which amounted to 103 which were used as research objects. The scale used as a measurement of variables in the answers or questionnaire content of the respondents is to use a Likert scale.

The method of multiple linear regression analysis is used to see the effect of leadership quality and organizational culture on the performance of educators and administrative staff.

Multiple Regression Analysis

Coefficientsa

\begin{tabular}{|c|c|c|c|c|c|c|}
\hline \multirow[t]{2}{*}{ Model } & \multicolumn{2}{|c|}{$\begin{array}{c}\text { Unstandardi } \\
\text { zed } \\
\text { Coefficients }\end{array}$} & $\begin{array}{c}\text { Standardi } \\
\text { zed } \\
\text { Coefficie }\end{array}$ & \multirow[t]{2}{*}{$\mathrm{t}$} & \multirow[t]{2}{*}{$\begin{array}{l}\mathrm{Si} \\
\mathrm{g} .\end{array}$} & $\begin{array}{c}\text { Correlati } \\
\text { ons }\end{array}$ \\
\hline & B & $\begin{array}{c}\text { Std. } \\
\text { Err } \\
\text { or }\end{array}$ & Beta & & & $\begin{array}{l}\text { Zero- } \\
\text { order }\end{array}$ \\
\hline (Constant) &,- 225 &, 113 & & $\begin{array}{r}- \\
1,99\end{array}$ & $\begin{array}{r}, 04 \\
8\end{array}$ & \\
\hline 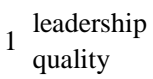 & 299 & ,064 & 290 & $\begin{array}{r}4,66 \\
2\end{array}$ & $\begin{array}{r}, 00 \\
0\end{array}$ & 843 \\
\hline $\begin{array}{l}\text { organizati } \\
\text { onal } \\
\text { culture }\end{array}$ & ,714 & 065 & ,684 & $\begin{array}{r}10,9 \\
98\end{array}$ & $\begin{array}{r}, 00 \\
0\end{array}$ & 918 \\
\hline
\end{tabular}

a. Dependent Variable: Employee Performance

Source: Primary data processed, 2019

\section{Multiple Regression Analysis}

Based on the calculation results in the above table, we get the form of multiple linear regression equations as follows:

$\mathrm{Y}=-0.225+0.299 \mathrm{X} 1+0.714 \mathrm{X} 2$

The value of the regression coefficient on the independent variables illustrates if it is estimated that the independent variable rises by one unit and the value of the other independent variables are estimated to be constant or equal to zero, then the value of the dependent variable is expected to go up or can go down in accordance with the sign of the regression coefficient of the independent variable.

The regression coefficient sign of the independent variable shows the direction of the relationship of the variable concerned with employee performance. The regression coefficient for the independent variable of leadership quality is positive, indicating a direct relationship between leadership quality and employee performance. The regression coefficient of physical evidence variable of 0.299 implies that for each increase in leadership quality by one unit will cause an increase in employee performance by 0.299 units.

The regression coefficient for the reliability independent variable is positive, indicating a direct relationship between organizational culture and employee performance. The regression coefficient of organizational culture variable of 0.714 implies that for each increase in organizational culture by one unit will cause 
an increase in employee performance by 0.714 units.

\section{Summary Model}

Model $\mathrm{R}_{\text {Square }}$ Adjusted R Square Std. An error of the Estimate

1, 843a, 710, 707, 33439

a. Predictors: (Constant), Quality of Leadership

Based on the SPSS output above, it is known that the $r$ count is 0.843 which shows that the strong influence between Leadership Quality and Employee Performance. This means that if the Quality of Leadership is improved, Employee Performance will be better.

To be able to find out whether the $r$ count is significant there needs to be a comparison between $r_{\text {table }}$ or by looking at the probability. Correlation is significant when the $r$ count is greater than rtable or the probability value is less than the level of error. Then it can be concluded that the correlation is positive.

The coefficient of determination (R2) is 0.710 , which means $71 \%$ variance on the influence of leadership quality on the performance of teaching staff and administrative staff with Std. An error of 0.334 .

\section{B. Research methods}

In this study as the population is the teaching staff and administrative staff at SMAN 28 Tangerang District, which amounted to 103 which were used as research objects. The scale used as a measurement of variables in the answers or questionnaire content of the respondents is to use a Likert scale.

\section{Discussion Analysis.}

The method of multiple linear regression analysis is used to see the effect of leadership quality and organizational culture on the performance of educators and administrative staff.

Multiple Linear Regression

Coefficients

\begin{tabular}{|c|c|c|c|c|c|c|}
\hline \multirow[t]{2}{*}{ Model } & \multicolumn{2}{|c|}{$\begin{array}{l}\text { Unstandardi } \\
\text { zed } \\
\text { Coefficients }\end{array}$} & $\begin{array}{l}\text { Standardi } \\
\text { zed } \\
\text { Coefficie }\end{array}$ & \multirow[t]{2}{*}{$\mathrm{t}$} & \multirow[t]{2}{*}{$\begin{array}{l}\mathrm{Si} \\
\mathrm{g} .\end{array}$} & $\begin{array}{l}\text { Correlati } \\
\text { ons }\end{array}$ \\
\hline & B & $\begin{array}{l}\text { Std. } \\
\text { Err } \\
\text { or }\end{array}$ & Beta & & & $\begin{array}{l}\text { Zero- } \\
\text { order }\end{array}$ \\
\hline $\begin{array}{l}\text { (Constant } \\
\text { ) }\end{array}$ &,- 225 & ,113 & & $\begin{array}{r}- \\
1,99 \\
9\end{array}$ & $\begin{array}{r}, 04 \\
8\end{array}$ & \\
\hline $\begin{array}{l}\text { Leadershi } \\
{ }_{1} \text { p Quality }\end{array}$ & 299 & ,064 & 290 & $\begin{array}{r}4,66 \\
2\end{array}$ & $\begin{array}{r}, 00 \\
0\end{array}$ & ,843 \\
\hline $\begin{array}{l}\text { Organizat } \\
\text { ion } \\
\text { Culture }\end{array}$ & ,714 & ,065 & 684 & $\begin{array}{r}10,9 \\
98\end{array}$ & $\begin{array}{r}, 00 \\
0\end{array}$ & 918 \\
\hline
\end{tabular}

Source: Primary data processed, 2019

Based on the calculation results in the above table, we get the form of multiple linear regression equations as follows:

$\mathrm{Y}=-0.225+0.299 \mathrm{X} 1+0.714 \mathrm{X} 2$

The value of the regression coefficient on the independent variables illustrates if it is estimated that the independent variable rises by one unit and the value of the other independent variables are estimated to be constant or equal to zero, then the value of the dependent variable is expected to go up or can go down in accordance with the sign of the regression coefficient of the independent variable. 
The regression coefficient sign of the independent variable shows the direction of the relationship of the variable concerned with employee performance. The regression coefficient for the independent variable of leadership quality is positive, indicating a direct relationship between leadership quality and employee performance. The regression coefficient of physical evidence variable of 0.299 implies that for each increase in leadership quality by one unit will cause an increase in employee performance by 0.299 units.

The regression coefficient for the reliability independent variable is positive, indicating a direct relationship between organizational culture and employee performance. The regression coefficient of organizational culture variable of 0.714 implies that for each increase in organizational culture by one unit will cause an increase in employee performance by 0.714 units.

Model Summary

\begin{tabular}{|l|r|r|r|r|}
\hline Model & R & R Square & $\begin{array}{c}\text { Adjusted R } \\
\text { Square }\end{array}$ & $\begin{array}{c}\text { Std. Error of } \\
\text { the Estimate }\end{array}$ \\
\hline 1 &, $843^{\mathrm{a}}$ &, 710 &, 707 &, 33439 \\
\hline
\end{tabular}

Based on the SPSS output above, the r-count of 0.843 shows that the strong influence between Leadership Quality and Employee Performance. This means that if the Quality of Leadership is improved, Employee Performance will be better.

To be able to find out whether the r-count is significant there needs to be a comparison between r-tables or by looking at the probability. Significant correlation when rcount is greater than r-table or the probability value is less than the level of error. Then it can be concluded that the correlation is positive.
The coefficient of determination $\left(\mathrm{R}^{2}\right)$ is 0.710 , which means $71 \%$ variance on the influence of leadership quality on the performance of teaching staff and administrative staff with Std. Error of 0.334.

Model Summary

\begin{tabular}{|l|r|r|r|r|}
\hline Model & \multicolumn{1}{|c|}{$\mathrm{R}$} & $\mathrm{R}$ Square & $\begin{array}{c}\text { Adjusted R } \\
\text { Square }\end{array}$ & $\begin{array}{c}\text { Std. Error of } \\
\text { the Estimate }\end{array}$ \\
\hline 1 &, $918^{\mathrm{a}}$ &, 843 &, 841 &, 24633 \\
\hline
\end{tabular}

a. Predictors: (Constant), Organization Culture

Based on the above SPSS output it is known that the r-count is 0.918 which shows that the strong influence between organizational culture and the performance of educators and administrative staff. This means that if organizational culture is improved employee performance will be better.To be able to find out whether the r-count is significant there needs to be a comparison between r-tables or by looking at the probability. Correlation is significant if $r$ count is greater than $r$-table or the probability value is less than the error level. Then it can be concluded that the correlation is positive. The coefficient of determination $\left(\mathrm{R}^{2}\right)$ of 0.843 , which means $84.3 \%$ of variance on the influence of organizational culture on the performance of educators and administrative staff with Std. Error of 0.2463.This coefficient of determination test is used to determine the magnitude of the contribution made between the quality of leadership and organizational culture on the performance of educators and administrative staff simultaneously. And the results of this test can be seen below the table as follows: 




Source: Primary Data Processing Results, 2019

Based on the SPSS software output above, a correlation coefficient (R) of 0.934 is obtained. This shows that there is a very strong relationship between the quality of leadership and organizational culture with the performance of educators and administrative staff. The magnitude of the influence of leadership and organizational culture on employee performance can be shown by the coefficient of determination with the following formula: $\mathrm{KD}=\mathrm{R}^{2} \mathrm{x}$ $100 \%,=(0.934) 2 \times 100 \%=87.2 \%$, meaning that the variable leadership and organizational culture provide an influence of $87,2 \%$ of employee performance. While the remaining $12.8 \%$ is contributed by other variables besides leadership and organizational culture.

The $\mathrm{F}$ test was conducted to be able to determine the significance of the effect of the independent variables simultaneously on the dependent variable. In this case, it is done by the $\mathrm{F}$ test and can be seen in the following table:
Overall Hypothesis Testing (Test F)

\begin{tabular}{|c|c|c|c|c|c|}
\hline $\begin{array}{c}\text { F } \\
\text { Count }\end{array}$ & df & $\begin{array}{c}\text { F } \\
\text { table }\end{array}$ & Sig & $\begin{array}{c}\text { Informati } \\
\text { on }\end{array}$ & Conclusion \\
\hline \multirow{3}{3}{$\begin{array}{c}326,52 \\
6\end{array}$} & df1 $=2$ & \multirow{2}{*}{3,091} & $\begin{array}{c}0.00 \\
0\end{array}$ & $\begin{array}{c}\text { Ho } \\
\text { refused }\end{array}$ & $\begin{array}{c}\text { There is } \\
\text { influence }\end{array}$ \\
\cline { 2 - 2 } & $\begin{array}{c}\text { df2 }= \\
96\end{array}$ & & & & (Significant) \\
\hline
\end{tabular}

From the table above, the calculated $\mathrm{F}$ value is 326,526 . Because the calculated $F$ value $(326,526)>\mathrm{F}$ table $(3,091)$, then $\mathrm{Ho}$ is rejected. Thus it can be concluded that simultaneously there is a significant influence of the quality of leadership and organizational culture on the performance of educators and administrative staff.The t-test is used to determine the validity of the relationship of each variable of the independent variable 1 leadership quality (X1) and the independent variable 2 organizational culture (X2) with the dependent variable performance of educators and administrative staff (Y), with a level of 0.05 . The results of the t-test can be seen from the table below:

\section{Partial Test Mean Calculation Results}

Coefficients $^{\mathrm{a}}$

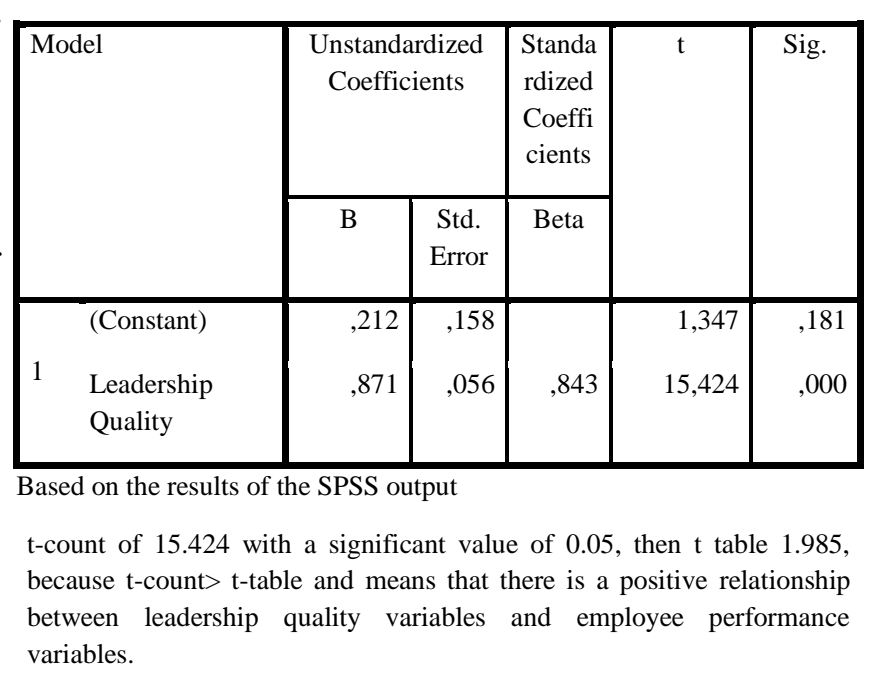

Partial Test Mean Calculation Results 
Coefficients $^{\mathrm{a}}$

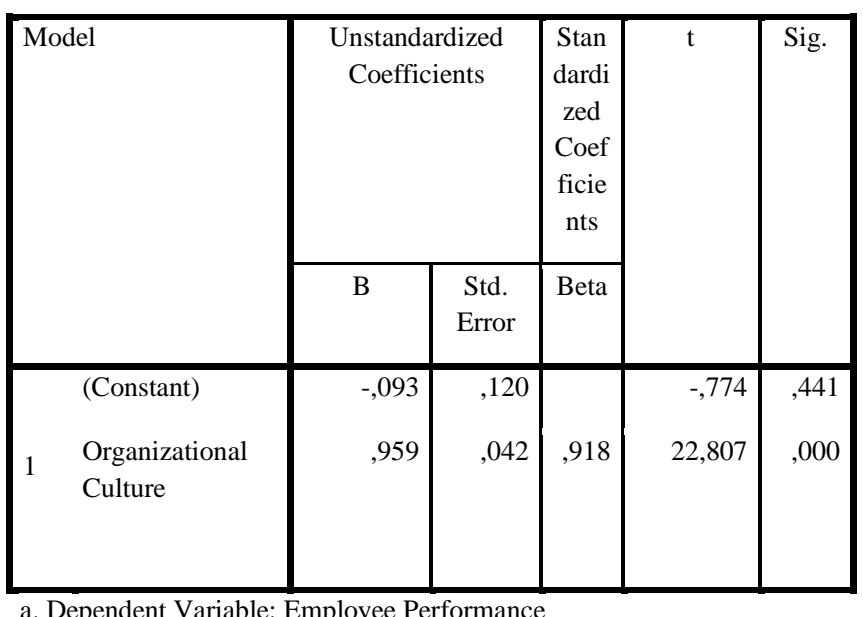

Dariable: Employee Performance

Based on the results of the SPSS output tcount of 22.807 with a significant value of 0.05 , the $\mathrm{t}$-table is 1.985 , because $\mathrm{t}$-count $>\mathrm{t}$ table and means that there is a positive relationship between organizational culture variables and performance variables of educators and administrative staff

\section{Conclusion}

Based on the explanation above, employee performance is an important factor in realizing the success of an organization. Employee performance does not stand alone but has many relationships, including the quality of leadership and organizational culture as the results of the above research. The concept of leadership quality and organizational culture seems to have a strong contribution to changes in the performance Bibliography of educators and administrative staff. This means that the higher or better the quality of leadership and organizational culture together, the higher or better employee performance. And vice versa the lower or worse the quality of leadership and organizational culture together, the lower or worse the performance of employees.

\section{Suggestion}

Implications of Management, the need for leaders in organizations to always motivate all employees to foster creativity and innovation, leaders always involve subordinates in every decision making. Improving the quality of human resources with moral, ethical and integrity elements through emotional, spiritual question (ESQ) training, public speaking training. It is hoped that growing awareness within employees, work is worship, which must be carried out with full responsibility and sincerity so that they have commitment and consistency in carrying out their daily duties. In the future become an employee who becomes a spiritual and social person. Peer teaching, fit and proper tests, assessment tests, open bidding in a transparent, merit system method so that the apparatus placed has the integrity and capabilities needed to achieve school performance goals.

Busro, Muhammad. 2017. Human Resource Management. Yogyakarta: Expert.

Dessler, Gary. 2011. Human Resource Management. Jakarta. Index Issuer.

Griffin, Ricky. 2000. Management, Issue 2. Jakarta. Erlangga

J. Kaloh. 2009. Head of Regional Leadership. (Pattern of Activities, Power, and Behavior of Regional Heads in the Implementation of Regional Autonomy). Jakarta. Sinar Grafika.

Kartono, Kartini. 2003. Leaders and Leadership (What Is Abnormal Leadership). Jakarta. P.T Raja Grafindo Persada. 
Munandar, U.S. 2001. Stress and Work Safety of Industrial and Organizational Psychology. Jakarta. University of Indonesia Publisher.

Stoner, James AF., R. Edward Freeman., Daniel R. Gilbert, JR. 1995. Management, 6th Edition. New Jersey. Prentice. Hall Inc.

Sudaryono. 2014. Consumer Behavior in Marketing Perspectives. Jakarta. Scholar of the Lantern.

Sutrisno, Edy. 2011. Jakarta Human Resources Management. Kencana.

Timothy C, Obiwuru., Andy T, Okwu., Victoria O, Akpa., And Idowu A, Nwankwee. 2011. Effect of Leadership Style on Organizational Performance: A Survey of Selected Small Enterprises in IKOSI - KETU Council Development Area of Lagos State, Nigeria. Australian Journal of Business and Management Research, 1 (7), 100-111. Retrieved from the Australian Business Management Research Journal Open Access journal. 